\section{Kidney \\ Blood Pressure Research}

\title{
Renalase Gene Polymorphism in Patients After Renal Allograft Transplantation
}

\author{
Andrzej Pawlik ${ }^{a}$ Maria Serdynskab Ewa Dabrowska-Zamojcin ${ }^{a}$ \\ Violetta Dziedziejkoc Krzysztof Safranowc ${ }^{c}$ Leszek Domanski ${ }^{b}$ \\ Kazimierz Ciechanowski ${ }^{b}$
}

aDepartment of Pharmacology; ${ }^{b}$ Department of Nephrology, Transplantology and Internal Medicine; 'Department of Biochemistry and Medical Chemistry, Pomeranian Medical University, Szczecin, Poland

\author{
Key Words \\ Renalase • Polymorphism • Kidney
}

\begin{abstract}
Background/Aims: Renalase is a recently discovered protein, which is likely involved in regulation of blood pressure in humans and animals. Previous studies suggest that renalase reflects kidney functioning. A common missense polymorphism in the flavin-adenine dinucleotide-binding domain of human renalase (Glu37Asp) has been described. In this study we examined the association between (Glu37Asp) polymorphism (rs2296545) in renalase gene and kidney allograft function. Methods: The study enrolled 270 Caucasian kidney allograft recipients. SNP within the renalase was genotyped using TaqMan genotyping assays. Results: There were no statistically significant associations between renalase gene rs2296545 polymorphism and delayed graft function, acute rejection, chronic allograft dysfunction as well as creatinine serum concentrations and blood pressure values after transplantation. Conclusions: The results of this study suggest, that renalase gene rs2296545 polymorphism is not important factor determining renal allograft function.
\end{abstract}

Copyright (C) 2014 S. Karger AG, Basel

\section{Introduction}

Renalase is a novel flavoprotein that is highly expressed in kidney and heart and probably metabolizes catecholamines and catecholamine-like substances [1]. Renalase is mainly expressed in the proximal tubules of the kidney and secreted in blood and urine. It has some similarities to monoamine oxidases, but distinct substrate specificity, indicating that it represents a new class of flavin-adenine dinucleotide (FAD) containing monoamine oxidases $[2,3]$. Later studies indicated renalase expression also in the liver, skeletal muscles, 


\section{Kidney Blood Pressure Research}

Kidney Blood Press Res 2014;39:58-64

\begin{tabular}{l|l}
\hline DOI: 10.1159/000355777 & (c) 2014 S. Karger AG, Basel
\end{tabular}

Published onlıne: June 03, 2014

www.karger.com/kbr

central nervous system, endothelium, and adipose tissues [4]. Renalase levels are regulated by: renal function, renal perfusion and catecholamine levels. There was a relationship between renalase levels, the glomerular filtration rate and kidney mass [5]. Marked renalase deficiency was observed in patients with end-stage renal disease (ESRD) [6].

Human renalase is encoded by a $311 \mathrm{Kbp}$ gene with 10 exons located on chromosome 10q23.33. The major isoform of renalase contains 342 amino acids comprising a signal peptide, a flavin-adenine dinucleotide (FAD) binding domain, and a monoamine oxidase domain [7]. The most common isoform (renalase1) is encoded by exons 1-4, 6-7, and 9. It is the predominant human renalase protein detectable in plasma and tissues. The functional significance of the spliced isoforms is not known. A common missense polymorphism in the flavin-adenine dinucleotide-binding domain of human renalase (Glu37Asp) has recently been described. The polymorphism rs2296545 G>C results in a conservative amino acid change (glutamic to aspartic acid at amino acid 37) within the FAD-binding domain [8]. This polymorphism was associated with cardiac hypertrophy, dysfunction, ischemia and hypertension [8]. Because circulatory system and blood pressure influence renal function, this polymorphism may also be associated with function of renal allograft.

In this study we examined the association between (Glu37Asp) polymorphism (rs2296545) in renalase gene and kidney allograft function.

\section{Material and Methods}

A total of 270 recipients of first renal transplants were included in the study (166 males, 104 females, mean age $47.63 \pm 12.96$ years; transplantation performed between 2001 and 2009 in the Clinical Department of Nephrology and Transplantology of the Pomeranian Medical University in Szczecin, Poland). The histories of the patients were analyzed, taking into account delayed graft function (DGF), acute rejection and chronic allograft dysfunction. DGF was defined as the need for hemodialysis within the first 7 days after transplantation. Acute rejection episodes were defined by clinical diagnosis (elevated serum creatinine in the absence of other pathology including infection, urinary tract obstruction, allograft artery stenosis or cyclosporine toxicity) and were confirmed by positive biopsy. Chronic allograft dysfunction was diagnosed by eliminating other causes such as: infections, urinary obstruction, allograft artery stenosis or cyclosporine toxicity and by changes in biopsy samples. This process was diagnosed clinically in patients having a slow persistent rise in serum creatinine at least $30 \%$ above baseline, usually accompanied by new or worsening hypertension and proteinuria (above $500 \mathrm{mg} / 24 \mathrm{~h}$ ). Anatomical problems were excluded by ultrasound and nuclear scans. Biopsy criteria included the presence of interstitial fibrosis, tubular atrophy and, particularly, characteristic vascular changes such as hypertrophy of the arterial intima and smooth muscle (intimal thickening) and glomerular sclerosis. All biopsies were reviewed by a renal pathologist and the Banff working classification criteria were used in the histological classification of the biopsies. Blood samples were collected from all patients for genetic analysis at the start of the study and for the evaluation of creatinine concentration 1, 3, 4, 12, 24 and 36 months after kidney transplantation. Creatinine concentration was measured using a colorimetric method. Deteriorating renal transplant function was verified via biopsy, which was reviewed by a renal pathologist using the Banff working classification criteria. Patients with hemoglobin A1c continuously over $6.5 \%$, fasting blood glucose $\geq 7.0 \mathrm{mmol} / \mathrm{l}$, or requiring treatment with oral hypoglycemic agents or insulin continued for more than 3 months after transplantation were diagnosed as having post-transplant diabetes mellitus PTDM [9].

Immunosuppressive therapy consisted of cyclosporine A, mycophenolate mofetil and prednisone. The study was approved by the local ethics committee and informed consent was obtained from all subjects.

\section{Genotyping}

SNP within the renalase gene was genotyped using TaqMan genotyping assays. Genomic DNA was extracted from $200 \mu \mathrm{L}$ of whole blood samples using a GeneMATRIX Quick Blood DNA Purification Kit (EURx, Poland). Fluorescence data was captured using a 7500 FAST Real-Time PCR System (Applied Biosystems, USA). 


\section{Kidney \\ Blood Pressure Research}

Kidney Blood Press Res 2014;39:58-64

DOI: $10.1159 / 000355777$

Published onlıne: June 03, 2014

C 2014 S. Karger AG, Base

www.karger.com/kbr

Table 1. The association between RNLS rs2296545 genotypes and delayed graft function (DGF)

\begin{tabular}{|c|c|c|c|c|c|c|c|c|}
\hline \multirow{2}{*}{$R N L S$ rs2296545 } & \multicolumn{2}{|c|}{ DGF } & \multicolumn{2}{|c|}{ Without DGF } & \multirow{2}{*}{ p-value ${ }^{\wedge}$} & & \multirow{2}{*}{ p-value ${ }^{*}$} & \multirow{2}{*}{ OR $(95 \% \mathrm{CI})$} \\
\hline & $\mathrm{n}$ & $\%$ & $\mathrm{n}$ & $\%$ & & & & \\
\hline \multicolumn{9}{|l|}{ genotype } \\
\hline GG & 14 & $25.57 \%$ & 35 & $71.43 \%$ & & $\mathrm{CC}+\mathrm{CG}$ vs GG & 0.74 & $1.18(0.60-2.34)$ \\
\hline $\mathrm{CG}$ & 42 & $33.60 \%$ & 83 & $66.40 \%$ & 0.77 & $\mathrm{CC}$ vs $\mathrm{CG}+\mathrm{GG}$ & 0.78 & $0.91(0.53-1.56)$ \\
\hline \multirow[t]{3}{*}{$\mathrm{CC}$} & 29 & $30.21 \%$ & 67 & $69.79 \%$ & & CC vs GG & 1.00 & $1.08(0.51-2.31)$ \\
\hline & & & & & & CG vs GG & 0.59 & $1.27(0.61-2.61)$ \\
\hline & & & & & & CC vs CG & 0.66 & $0.86(0.48-1.52)$ \\
\hline \multicolumn{9}{|l|}{ allele } \\
\hline $\mathrm{G}$ & 70 & $41.18 \%$ & 153 & $41.35 \%$ & & & & \\
\hline $\mathrm{C}$ & 100 & $58.82 \%$ & 217 & $58.65 \%$ & & C vs G & 1.00 & $1.01(0.70-1.46)$ \\
\hline
\end{tabular}

Table 2. The association between RNLS rs2296545 genotypes and acute rejection

\begin{tabular}{|c|c|c|c|c|c|c|c|c|}
\hline \multirow[t]{2}{*}{$R N L S$ rs2296545 } & \multicolumn{2}{|c|}{ Acute rejection } & \multicolumn{2}{|c|}{$\begin{array}{l}\text { Without acute } \\
\text { rejection }\end{array}$} & \multirow[t]{2}{*}{ p-value ${ }^{\wedge}$} & & \multirow[t]{2}{*}{ p-value ${ }^{*}$} & \multirow[t]{2}{*}{ OR $(95 \% \mathrm{CI})$} \\
\hline & $n$ & $\%$ & $\mathrm{n}$ & $\%$ & & & & \\
\hline \multicolumn{9}{|l|}{ genotype } \\
\hline GG & 13 & $26.53 \%$ & 36 & $73.47 \%$ & & $\mathrm{CC}+\mathrm{CG}$ vs GG & 1.00 & $0.96(0.48-1.94)$ \\
\hline CG & 34 & $27.20 \%$ & 91 & $72.80 \%$ & 0.86 & $\mathrm{CC}$ vs $\mathrm{CG}+\mathrm{GG}$ & 0.66 & $0.85(0.48-1.51)$ \\
\hline \multirow{3}{*}{ CC } & 23 & $23.96 \%$ & 73 & $76.04 \%$ & & CC vs GG & 0.84 & $0.87(0.40-1.92)$ \\
\hline & & & & & & CG vs GG & 1.00 & $1.03(0.49-2.18)$ \\
\hline & & & & & & CC vs CG & 0.64 & $0.84(0.46-1.56)$ \\
\hline \multicolumn{9}{|l|}{ allele } \\
\hline G & 60 & $42.86 \%$ & 163 & $40.75 \%$ & & & & \\
\hline $\mathrm{C}$ & 80 & $57.14 \%$ & 237 & $59.25 \%$ & & C vs G & 0.69 & $0.92(0.62-1.35)$ \\
\hline
\end{tabular}

Statistical analysis

The distribution of the genotypes and alleles was evaluated using the chi-square test with Yates' correction or Fishers' exact test. The serum concentrations of creatinine were compared between genotype groups using the non-parametric Kruskal-Wallis test. A p-value $<0.05$ was considered statistically significant.

\section{Results}

The GG genotype was present in $18.1 \%$, the CG in $46.3 \%$ and the CC in $35.6 \%$ of the recipients. The distribution of genotypes studied was in Hardy-Weinberg equilibrium (p-value: 0.45 ).

Delayed graft function was diagnosed in $25.57 \%$ of the patients with the GG genotype, $33.60 \%$ with CG and $30.21 \%$ with CC. The differences were not statistically significant (Table 1).

Acute rejection was diagnosed in $26.53 \%$ of the carriers of the GG genotype, $27.20 \%$ of CG carriers and $23.96 \%$ of those with CC. The differences were not statistically significant (Table 2).

Chronic allograft dysfunction was diagnosed in $28.57 \%$ of the patients with the GG genotype, $21.60 \%$ with CG and $21.88 \%$ with CC. The differences were not statistically significant (Table 3).

Post-transplant diabetes mellitus was diagnosed in $13.33 \%$ of the patients with the GG genotype, $14.46 \%$ with CG and $12.50 \%$ with CC. The differences were not statistically significant (Table 4). 


\section{Kidney \\ Blood Pressure Research}

Pawlik/Serdynska/Dabrowska-Zamojcin, et al.: Renalase Polymorphism in Patients After Renal Transplantation

Table 3. The association between $R N L S$ rs2296545 genotypes and chronic allograft dysfunction

\begin{tabular}{|c|c|c|c|c|c|c|c|c|}
\hline \multirow[t]{2}{*}{$R N L S$ rs2296545 } & \multicolumn{2}{|c|}{$\begin{array}{c}\text { Chronic } \\
\text { allograft } \\
\text { dysfunction } \\
\end{array}$} & \multicolumn{2}{|c|}{$\begin{array}{c}\text { Without } \\
\text { chronic allograft } \\
\text { dysfunction }\end{array}$} & \multirow[t]{2}{*}{ p-value ${ }^{\wedge}$} & & \multirow[t]{2}{*}{ p-value* } & \multirow[t]{2}{*}{ OR $(95 \% \mathrm{CI})$} \\
\hline & $\mathrm{n}$ & $\%$ & $\mathrm{n}$ & $\%$ & & & & \\
\hline \multicolumn{9}{|l|}{ genotype } \\
\hline $\mathrm{GG}$ & 14 & $28.57 \%$ & 35 & $71.43 \%$ & & $\mathrm{CC}+\mathrm{CG}$ vs $\mathrm{GG}$ & 0.35 & $0.69(0.35-1.40)$ \\
\hline CG & 27 & $21.60 \%$ & 98 & $78.40 \%$ & 0.59 & $\mathrm{CC}$ vs $\mathrm{CG}+\mathrm{GG}$ & 0.88 & $0.90(0.50-1.70)$ \\
\hline \multirow[t]{3}{*}{$\mathrm{CC}$} & 21 & $21.88 \%$ & 75 & $78.13 \%$ & & CC vs GG & 0.41 & $0.70(0.32-1.54)$ \\
\hline & & & & & & CG vs GG & 0.33 & $0.68(0.32-1.50)$ \\
\hline & & & & & & CC vs CG & 1.00 & $1.01(0.53-1.94)$ \\
\hline \multicolumn{9}{|l|}{ allele } \\
\hline $\mathrm{G}$ & 55 & $44.35 \%$ & 168 & $40.38 \%$ & & & & \\
\hline $\mathrm{C}$ & 69 & $55.65 \%$ & 248 & $59.62 \%$ & & C vs G & 0.47 & $0.85(0.57-1.27)$ \\
\hline
\end{tabular}

Table 4. The association between RNLS rs2296545 genotypes and post-transplant diabetes mellitus (PTDM)

\begin{tabular}{|c|c|c|c|c|c|c|c|c|}
\hline \multirow[t]{2}{*}{$R N L S$ rs2296545 } & \multicolumn{2}{|c|}{ PTDM } & \multicolumn{2}{|c|}{ Without PTDM } & \multirow{2}{*}{ p-value ${ }^{\wedge}$} & & \multirow{2}{*}{ p-value ${ }^{*}$} & \multirow{2}{*}{ OR $(95 \% \mathrm{CI})$} \\
\hline & $\mathrm{n}$ & $\%$ & $\mathrm{n}$ & $\%$ & & & & \\
\hline \multicolumn{9}{|l|}{ genotype } \\
\hline GG & 4 & $13.33 \%$ & 26 & $86.67 \%$ & & $\mathrm{CC}+\mathrm{CG}$ vs $\mathrm{GG}$ & 1.00 & $1.03(0.32-3.28)$ \\
\hline CG & 12 & $14.46 \%$ & 71 & $88.54 \%$ & 0.95 & $\mathrm{CC}$ vs $\mathrm{CG}+\mathrm{GG}$ & 1.00 & $0.87(0.33-2.24)$ \\
\hline \multirow[t]{3}{*}{$\mathrm{CC}$} & 7 & $12.50 \%$ & 49 & $87.50 \%$ & & CC vs GG & 1.00 & $0.93(0.25-3.47)$ \\
\hline & & & & & & CG vs GG & 1.00 & $1.09(0.33-3.71)$ \\
\hline & & & & & & CC vs CG & 0.80 & $0.85(0.31-2.30)$ \\
\hline \multicolumn{9}{|l|}{ allele } \\
\hline G & 20 & $43.48 \%$ & 123 & $42.12 \%$ & & & & \\
\hline $\mathrm{C}$ & 26 & $56.52 \%$ & 169 & $57.88 \%$ & & C vs G & 0.97 & $0.95(0.51-1.77)$ \\
\hline
\end{tabular}

${ }^{\wedge} \chi^{2}$ test; ${ }^{*}$ Fisher's exact test

Creatinine concentrations 1, 3, 6,12,24 and 36 months after transplantation did not differ significantly between the different genotypes and alleles of the renalase gene rs2296545 polymorphism (Table 5). Likewise, the blood pressure values after transplantation were not associated with the renalase gene rs2296545 polymorphism (Table 6).

The causes of renal failure in renal allograft recipients were: chronic glomerulonephritis (58\%), hypertension (9\%), diabetes (9\%), chronic pyelonephritis (5\%), systemic lupus erythomatosus (4\%), autosomal dominant polycystic kidney disease (4\%), vesico-ureteral reflux (3\%) and Alport syndrome (1\%). The cause of renal failure remained unknown in $7 \%$ of studied patients. We analyzed the associations between causes of renal failure and renalase genotypes; the differences were not statistically significant.

\section{Discussion}

In this study we analyzed the association between the renalase gene rs2296545 polymorphism and kidney allograft function. There were no statistically significant associations between this polymorphism and early and late graft function.

In recent years, renalase has been found to be closely related to the activity of the renal sympathetic nerves and blood pressure [10]. Clinical and animal studies have shown that the increased activity of the sympathetic nerves and elevation of blood pressure are usually accompanied by reduction in renalase expression, and that renalase deficiency may cause an increase in blood pressure and activity of the sympathetic nerves [3]. 


\section{Kidney Blood Pressure Research}

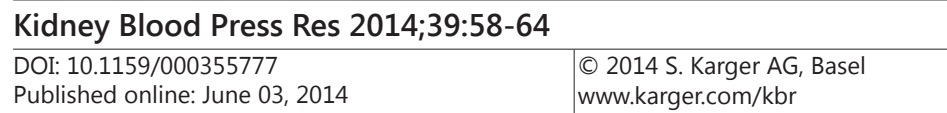

www.karger.com/kbr

Pawlik/Serdynska/Dabrowska-Zamojcin, et al.: Renalase Polymorphism in Patients After Renal Transplantation

Table 5. The association between $R N L S$ rs2296545 genotypes and serum creatinine after transplantation

\begin{tabular}{|c|c|c|c|c|c|c|c|c|}
\hline & \multirow{3}{*}{$\begin{array}{c}\text { Time after } \\
\text { transplantation } \\
{[\text { month] }}\end{array}$} & \multicolumn{6}{|c|}{ RNLS rs2296545 genotype } & \multirow{3}{*}{$\mathrm{p}^{\mathrm{a}}$} \\
\hline & & \multicolumn{2}{|c|}{ GG } & \multicolumn{2}{|c|}{ CG } & \multicolumn{2}{|c|}{$\mathrm{CC}$} & \\
\hline & & Mean & SD & Mean & SD & Mean & SD & \\
\hline \multirow{6}{*}{$\begin{array}{l}\text { Serum } \\
\text { creatinine } \\
{[\mathrm{mg} / \mathrm{dL}]}\end{array}$} & 1 & 1.79 & 0.71 & 1.86 & 0.85 & 1.88 & 0.98 & 0.70 \\
\hline & 3 & 1.74 & 0.57 & 1.77 & 0.58 & 1.76 & 0.66 & 0.93 \\
\hline & 6 & 1.76 & 0.50 & 1.78 & 0.63 & 1.79 & 0.73 & 0.82 \\
\hline & 12 & 1.83 & 0.71 & 1.78 & 0.61 & 1.69 & 0.56 & 0.43 \\
\hline & 24 & 1.78 & 0.65 & 1.77 & 0.62 & 1.70 & 0.56 & 0.67 \\
\hline & 36 & 1.72 & 0.68 & 1.69 & 0.56 & 1.77 & 0.62 & 0.69 \\
\hline
\end{tabular}

Table 6. The association between RNLS rs2296545 genotypes and blood pressure after transplantation

\begin{tabular}{|c|c|c|c|c|c|c|c|c|}
\hline & \multirow{3}{*}{$\begin{array}{c}\text { Time after } \\
\text { transplantation } \\
\text { [month] }\end{array}$} & \multicolumn{6}{|c|}{ RNLS rs2296545 genotype } & \multirow{3}{*}{$\mathrm{p}^{\mathrm{a}}$} \\
\hline & & \multicolumn{2}{|c|}{ GG } & \multicolumn{2}{|c|}{ CG } & \multicolumn{2}{|c|}{$\mathrm{CC}$} & \\
\hline & & Mean & SD & Mean & SD & Mean & SD & \\
\hline Systolic & 1 & 141.8 & 23.1 & 139.2 & 16.9 & 137.9 & 18.6 & 0.85 \\
\hline Blood & 3 & 140.9 & 14.0 & 138.7 & 16.7 & 137.7 & 18.5 & 0.48 \\
\hline Pressure & 6 & 142.3 & 16.3 & 139.0 & 19.7 & 140.6 & 20.7 & 0.50 \\
\hline$[\mathrm{mmHg}]$ & 12 & 144.3 & 21.8 & 137.9 & 17.0 & 134.5 & 14.8 & 0.11 \\
\hline Diastolic & 1 & 90.5 & 21.9 & 86.8 & 14.6 & 85.9 & 12.3 & 0.89 \\
\hline Blood & 3 & 84.2 & 9.1 & 86.4 & 10.8 & 85.5 & 11.7 & 0.46 \\
\hline Pressure & 6 & 86.1 & 11.1 & 86.2 & 10.2 & 87.9 & 10.3 & 0.21 \\
\hline [mmHg] & 12 & 90.2 & 12.4 & 86.4 & 10.6 & 85.3 & 8.5 & 0.27 \\
\hline
\end{tabular}

Studies have shown that kidneys are the main source of renalase production [6]. Moreover renalase can degrade catecholamines and has enzymatic hydrolysis action against dopamine, followed by adrenaline and noradrenaline [3]. Renalase is the only enzyme known to be secreted into blood that can degrade circulating catecholamine and may have a great value in prevention of kidney and cardiovascular diseases. Previous studies have demonstrated the possible effects of renalase in chronic renal failure and cardiovascular diseases [11]. Data from clinical studies has shown that renalase level significantly decrease in patients with stroke and chronic kidney diseases [12-17], whereas elevated levels of renalase in heart and kidney transplant recipients were observed. The increased levels of renalase were predominantly dependent on kidney function, which deteriorates with time after transplantation [12-14]. Likewise, elevated renalase levels in hemodialysis patients may be due to impaired kidney function and correlated with creatinine and residual renal function [15-17].

So far the polymorphisms in the renalase gene were not widely investigated. The studies have examined the relationship between polymorphisms in the renalase gene and the risk of development of hypertension, coronary artery disease, stroke and diabetes. Because abovementioned diseases may influence renal function this polymorphism may also be associated with function of renal allograft.

Zhao et al. examined renalase gene polymorphisms in patients with hypertension. These authors revealed that rs2576178 GG and rs2296545 CC genotypes were associated with an increased risk of hypertension in Chinese population [18]. Buraczynska et al. investigated the involvement of renalase gene polymorphisms in hypertension in type 2 diabetes patients [19]. The C allele of rs2296545 SNP was associated with hypertension. For rs2576178 SNP, genotype frequencies in hypertensive patients differed from controls, 


\section{Kidney \\ Blood Pressure Research}

Kidney Blood Press Res 2014;39:58-64

\begin{tabular}{l|l}
\hline DOI: 10.1159/000355777 & (c) 2014 S. Karger AG, Basel
\end{tabular}

Published onlıne: June 03, 2014

www.karger.com/kbr

Pawlik/Serdynska/Dabrowska-Zamojcin, et al.: Renalase Polymorphism in Patients After Renal Transplantation

but not from normotensive patients. For rs10887800 SNP, the differences in the G allele frequencies were observed in hypertensive patients with stroke. Stec et al. assessed the relationship of two renalase gene polymorphisms with hypertension in dialyzed patients [20]. They found that not only the $G$ allele frequencies of rs 2576178 showed a significantly higher incidence, but also $\mathrm{G}$ allele frequencies of rs10887800 showed a significantly higher incidence in hypertensive hemodialysis patients. The carrier state of the $G$ allele of the rs2576178 polymorphism was associated with a 1.55 fold higher risk of hypertension, while the carrier state of the $\mathrm{G}$ allele of the rs10887800 polymorphism was associated with 1.76 fold higher risk. Fava et al. assessed whether the polymorphisms in renalase gene (rs2576178 and rs2296545) could affect blood pressure levels, hypertension prevalence, and risk of incident cardiovascular events [21]. The data of these authors do not support an important role for the renalase polymorphisms in determining blood pressure and development of hypertension. Farzaneh-Far et al. examined renalase gene SNP (rs2296545) in patients with coronary artery disease [8]. The GG and CG genotypes were associated with cardiac hypertrophy, ventricular dysfunction, poor exercise capacity, and inducible ischemia in persons with stable coronary artery disease. Zhang et al. found close relation between renalase polymorphisms and stroke [22]. Two polymorphisms rs10887800 and rs2576178 were significantly associated with ischemic stroke and hypertension.

\section{Conclusion}

In this study there were no statistically significant association between renalase gene rs2296545 polymorphism and kidney allograft function as well as creatinine serum concentrations and blood pressure values after transplantation. This lack of association may be due to altered regulation of renalase production in transplanted kidney. The regulation of renalase production is not fully known. Previous studies on animal model showed that renal denervation was associated with increased plasma renalase concentration and renalase expression in the kidneys in hypertensive rats [23]. Probably other factors than genetic polymorphisms play the crucial role in the regulation of renalase production in transplanted kidney, nevertheless this hypothesis requires further investigations.

\section{Disclosure Statement}

The authors of this manuscript state that they have not any conflicts to declare.

\section{References}

1 Xu J, Li G, Wang P, Velazquez H, Yao X, Li Y, Wu Y, Peixoto A, Crowley S, Desir GV: Renalase is a novel, soluble monoamine oxidase that regulates cardiac function and blood pressure. J Clin Invest 2005;115:1275-1280.

$\checkmark 2$ Luft FC: Renalase, a catecholamine-metabolizing hormone from the kidney. Cell Metab 2005;1:358-360.

-3 Li G, Xu J, Wang P, Velazquez H, Li Y, Wu Y, Desir GV: Catecholamines regulate the activity, secretion, and synthesis of renalase. Circulation 2008;117:1277-1282.

4 Wang J, Qi S, Cheng W, Li L, Wang F, Li YZ, Zhang SP: Identification, expression and tissue distribution of a renalase homologue from mouse. Mol Biol Rep 2008;35:613-620.

-5 Malyszko J, Zbroch E, Malyszko JS, Koc-Zorawska E, Mysliwiec M: Renalase, a novel regulator of blood pressure, is predicted by kidney function in renal transplant recipients. Transplant Proc 2011;43:30043007.

6 Desir GV: Renalase deficiency in chronic kidney disease, and its contribution to hypertension and cardiovascular disease. Curr Opin Nephrol Hypertens 2008;17:181-185. 


\section{Kidney \\ Blood Pressure Research}

Kidney Blood Press Res 2014;39:58-64

\begin{tabular}{l|l}
\hline DOI: $10.1159 / 000355777$ & (C) 2014 S. Karger AG, Basel
\end{tabular}

Published onlıne: June 03, 2014 www.karger.com/kbr

7 Desir GV: Renalase is a novel renal hormone that regulates cardiovascular function. J Am Soc Hypertens 2007;1:99-103.

8 Farzaneh-Far R, Desir GV, Na B, Schiller NB, Whooley MA: A functional polymorphism in renalase (Glu37Asp) is associated with cardiac hypertrophy, dysfunction, and ischemia: data from the heart and soul study. PLoS One 2010;5:e13496.

-9 Davidson J, Wilkinson A, Dantal J, Dotta F, Haller H, Hernández D, Kasiske BL, Kiberd B, Krentz A, Legendre C, Marchetti P, Markell M, van der Woude FJ, Wheeler DC; International Expert Panel: New-onset diabetes after transplantation: 2003 International consensus guidelines. Proceedings of an international expert panel meeting. Barcelona, Spain, 19 February 2003. Transplantation 2003;75:SS3-S24.

$>10$ Desir GV: Regulation of blood pressure and cardiovascular function by renalase. Kidney Int 2009;76:366370.

11 Desir G: Novel insights into the physiology of renalase and its role in hypertension and heart disease. Pediatr Nephrol 2012;27:719-725.

12 Przybylowski P, Malyszko J, Kozlowska S, Koc-Zorawska E, Mysliwiec M: Serum renalase depends on kidney function but not on blood pressure in heart transplant recipients. Transplant Proc 2011;43:3888-3891.

$\checkmark 13$ Zbroch E, Malyszko J, Koc-Zorawska E, Mysliwiec M: Renalase, kidney function, and markers of endothelial dysfunction. Pol Arch Med Wewn 2012;122:40-44.

14 Koc-Zorawska E, Malyszko J, Malyszko JS, Mysliwiec M: VAP-1, a novel molecule linked to endothelial damage and kidney function in kidney allograft recipients. Kidney Blood Press Res 2012;36:242-247.

15 Malyszko J, Koc-Zorawska E, Malyszko JS, Kozminski P, Zbroch E, Mysliwiec M: Renalase, stroke, and hypertension in hemodialyzed patients. Ren Fail 2012;34:727-731.

-16 Zbroch E, Malyszko J, Koc-Zorawska E, Mysliwiec M: Renalase in peritoneal dialysis patients is not related to blood pressure, but to dialysis vintage. Perit Dial Int 2012;32: 348-351.

$>17$ Zbroch E, Malyszko J, Malyszko JS, Koc-Zorawska E, Mysliwiec M: Renalase, a Novel Enzyme Involved in Blood Pressure Regulation, Is Related to Kidney Function but Not to Blood Pressure in Hemodialysis Patients. Kidney Blood Press Res 2012;35: 395-399.

18 Zhao Q, Fan Z, He J, Chen S, Li H, Zhang P, Wang L, Hu D, Huang J, Qiang B, Gu D: Renalase gene is a novel susceptibility gene for essential hypertension: a two-stage association study in northern Han Chinese population. J Mol Med (Berl) 2007;85:877-885.

19 Buraczynska M, Zukowski P, Buraczynska K, Mozul S, Ksiazek A: Renalase gene polymorphisms in patients with type 2 diabetes, hypertension and stroke. Neuromolecular Med 2011;13:321-327.

-20 Stec A, Semczuk A, Furmaga J, Ksiazek A, Buraczynska M: Polymorphism of the renalase gene in end-stage renal disease patients affected by hypertension. Nephrol Dial Transplant 2012;27:4162-4166.

21 Fava C, Montagnana M, Danese E, Sjögren M, Almgren P, Engström G, Hedblad B, Guidi GC, Minuz P, Melander 0: The Renalase Asp37Glu polymorphism is not associated with hypertension and cardiovascular events in an urban-based prospective cohort: the Malmö Diet and cancer study. BMC Med Genet 2012;13:57.

-22 Zhang R, Li X, Liu N, Guo X, Liu W, Ning C, Wang Z, Sun L, Fu S: An association study on renalase polymorphisms and ischemic stroke in a Chinese population. Neuromolecular Med 2013;15:396-404.

-23 Jiang W, Guo Y, Tan L, Tang X, Yang Q, Yang K: Impact of renal denervation on renalase expression in adult rats with spontaneous hypertension. Exp Ther Med 2012;4:493-496. 